\title{
Importance of Mucopolysaccharides in the Development of the Protective Hepatotropic Effect of Hypothyrosis
}

\author{
A. Kulcsảr, I. Földes and J. Kulcsár-Gergely \\ The First Medical Clinic (Prof. B. Fornet), \\ Department of Anatomy, Histology and Embryology (Prof. St. Krompecher), \\ and Department of Pharmacology (Prof. T. Vályi-Nagy), \\ Medical University, Debrecen, Hungary
}

Modifications of mucopolysaccharide (MPS) content were investigated in the livers of thyroidectomized, thyroidectomized plus $\mathrm{CCl}_{4}$-treated and in non-thyroidectomized $\mathrm{CCl}_{4}$-treated rats using histological and histochemical methods.

Thyroidectomy seems to decrease the amount of MPS in the liver, inhibiting at the same time depolymerization and accumulation of acid MPS.

On $\mathrm{CCl}_{4}$ treatment increased amounts of acid MPS were noted. Hepatotoxic effect was found to be concomitant with increased depolymerization.

After thyroidectomy the characteristic damaging effects of $\mathrm{CCl}_{4}$ treatment could not assert themselves, the histological pattern of the livers being similar to that of thyroidectomized rats. These examinations seem to indicate a parallelism between MPS and changes of hepatoendocrine correlations.

The histological examinations confirmed the histochemical results.

On the basis of the results obtained the present authors believe that changes occurring in the polymerization, quantity and quality of MPS may contribute to increase the capacity of the liver to inactivate estrogen, and to counteract the hepatotoxic effect of $\mathrm{CCl}_{4}$ treatment in cases of hypothyrosis.

From the results of previons investigations, the present authors point out the interrelation between tryptophan and MPS metabolism.

The role and importance of mucopolysaccharides (MPS) in various branches of medical research are to-day in the center of interest. Since the first review of Levene $^{1}$ published in 1925, numerous data have been accumulating on the chemistry, physiology and pathophysiology of mucopolysaccharides. Some authors claimed that these protein-carbohydrate compounds have no specific function whatever and are only products of tissue disintegration. But this does not seem to be acceptable. ${ }^{2,3}$ It has been demonstrated for example that acid and neutral MPS are essential components of connective tissue fibers, ${ }^{4-6}$ since the fibers devoid of neutral MPS are unable to function. ${ }^{7-9}$ It has been also demonstrated that apart from their role played in formation of supporting tissues MPS participates actively in processes of growth, regeneration, fecundation and multiplication. ${ }^{10}$ In addition, the MPS are involved in certain pathological processes, ${ }^{11-22}$ in water and salt household ${ }^{10,23}$ and in certain enzyme activities, ${ }^{10,24}$ as well as in the interaction of the living organism and microorganisms. ${ }^{25-28}$

Received for publication, January 17, 1969. 
The regulation of MPS formation is, however, an unclarified question, though they are known to be influenced by hormonal and enzymatic factors. Vitamins too seem to have an effect on MPS formation. In endocrine regulation the hypophysis-thyroid-adrenal system is mainly involved. ${ }^{29-36}$ Sexual hormones, $13,23,37-41,43$ and hormones from the parathyroid glands and islets of Langerhans seem also to have regulating effects.

Numerous investigations were carried out on the metabolic disturbances of these large molecular protein-carbohydrate compounds in diseases of the liver ${ }^{44,46}$ and the neutral MPS level of the serum was found to decrease in hepatitis, and cirrhosis and toxic injuries of the liver. Impairments of the liver cells are accompanied by characteristic qualitative and quantitative alterations probably due to reduced formation of globulin fractions which are able to bind carbohydrates. The indirect role of the liver may also be interpreted as having an activating or inactivating effect on the hormones influencing MPS formation. The morphological substrates of these processes are probably the fibroblasts, mastocytes and chondrocytes $^{13,47,49}$ which are the sites of MPS production on the one hand, and the points of attack of hormones on the other. In this sense we may speak of a hepato-endocrine regulation of MPS. The work of Berencsi et al. ${ }^{29.50}$ referring to this correlation demonstrated that the thyroid function and the hexosamine content of the serum are closely related. These authors found that on $\mathrm{CCl}_{4}$ treatment the serum hexosamine level decreased, whereas this effect of $\mathrm{CCl}_{4}$ treatment did not persist after thyroidectomy. The toxic effect of $\mathrm{CCl}_{4}$ was evidenced by the presence of Hale positive material, especially in the Kupffer cells.

The study of the correlations between hepatic and endocrine functions seemed all the more to be of interest since numerous interrelations have been demonstrated between thyroid and hepatic, as well as between hepatic and endocrine functions in our previous experiments verifying the role of hepato-endocrine system in normal and pathological metabolic processes. In the present investigation we have attempted to clarify thyreo-hepatic correlations in MPS metabolism, i.e., I) the quantitative and qualitative relations of MPS and their degree of polymerization; 2) whether they undergo regular modifications which may be of diagnostic value; and 3) whether they are involved in the thyreo-hepatic correlations described previously by us.

In connection with these questions we remind here some of the results obtained in previous investigations which prompted us to perform the present experiments.

Thyroidectomized animals must be given a much higher dose of estrogen than non-operated controls to evole the same estrus reaction. From various experiments it was suggested that the capacity of the liver to inactivate estrogen increases after thyroidectomy. 51,54

Chronic $\mathrm{CCl}_{4}$ treatment was found to have a very moderate damaging effect on the liver of thyroidectomized rats. According to histological evidence thyroidectomy decreases the toxic effect of $\mathrm{CCl}_{4}$ treatment on the liver. ${ }^{55,58}$ 
The adaptive enzyme synthesis of tryptophanpyrrolase appears to be increased in hypothyrosis, and consequently the protein synthesis becomes likewise accelerated. ${ }^{59}$

\section{Materials and Methods}

Experiments were conducted on 20 female albino rats weighing about $200 \mathrm{~g}$. The rats were divided into four groups comprising five animals each: Group I, intact controls;

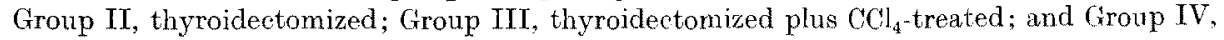
$\mathrm{CCl}_{4}$-treated. Thyroidectomy was performed under ether anesthesia. Six weeks after operation the rats were subjected to $\mathrm{CCl}_{4}$ treatment according to the method of Kanfmann. ${ }^{60}$ The duration of treatment was 7 weeks. The animals were killed by decapitation, and the livers were immediately removed for histological and histochemical examinations. The liver pieces were fixed in neutral formalin or in Sust fuid, and embedded in paraffin. The sections were stained with hematoxylin-chromotrop and azan. The histochemical procedures were as follows: Ritter-Oleson's method ${ }^{11}$ by which acid and neutral MPS can be demonstrated and differentiated. This method consists of the simultaneous employment of Hale's staining with Berlin blue 62 and Hotschkiss ${ }^{63}$ periodic acid Schiff PAS reaction. By the former procedure acid MPS are stained blue, whereas by the latter one neutral MPS are stained red. PAS reaction was controlled by acetylation and desacetylation, as well as by digestion with saliva. Acetylation was performed with acetic acid anhydride and pyridine to block the hydroxyl and amino groups. Desacetylation was carried out with $0,1 \mathrm{~N} \mathrm{KOH}$, by which the aminohydroxyl groups were released. Digestion with saliva was performed at $37^{\circ} \mathrm{C}$ for $10-12$ hours to rule ont glycogen.

\section{Results}

The results of examination are explained with the following figures.

\section{Histology}

Fig. 1. Microscopic picture of normal liver displaying regular trabecular arrangement, with normally wide sinuses.

Fig. 2. Following thyroidectomy no essential alterations may be noted in the histologic pattern of the liver. The liver cells are of normal size. Regular liver structure and moderately wide sinuses are present.

Fig. 3. After carbontetrachloride treatment insular lesions appear in the liver. The plasma of the liver cells displays abundant vacuolization. The sinuses are narrow, and an increased amount of cirrhotic connective tissue may be seen perilobularly. The number of mast cells increases considerably, especially in the vicinity of the venae centrales. The quantitative estimation of these findings will be performed in further investigations.

Fig. 4. No serious liver impairments can be observed after $\mathrm{CCl}_{4}$ treatment plus thyroidectomy. Some cells exhibit a slight structural disorganization in their plasma. Regular trabecular arrangement and moderately wide sinuses are visible.

\section{Histochemistry}

Fig. 5. The liver cells forming the trabeculae display in normal control rats a moderately strong PAS positivity, which disappears on acetylation but is 
restored on desacetylation. Only PAS positivity resistant to digestion by saliva was taken into consideration.

Fig. 6. After thyroidectomy, PAS positivity decreases in the liver cells. This decrease is, however, not uniform.

Fig. 7 . The most conspicuous feature of $\mathrm{CCl}_{4}$-treated group is the appearance of Hale positive reaction parallel with the injury of the liver cells. Hale positive areas appear mostly in the sinuses in the vicinity of the venae centrales. The injured liver cells show an increased Hale positivity due to enhanced depolymerization (Graumann ${ }^{67)}$. Owing to strong vacuolization of the liver cells, PAS positivity is not uniform within the cell either.

Fig. 8. There is no essential difference between PAS positivity of the liver cells of thyroidectomized plus $\mathrm{CCl}_{4}$-treated rats and those of merely thyroidectomized rats. The distribution of PAS positive areas in the cells is likewise not uniform. Simultaneous control examinations have been carried out in all groups.

\section{DIsCUSSION}

According to the majority of authors the changes of serum MPS level are considered to be indicators in myxedema or in experimental hypothyrosis. ${ }^{64}$ The data in the literature are, however, not concordant as to what changes does MPS undergo in the organs under similar conditions. While the oseillation of the serum MPS level and that of thyroid activity were found to be antagonistic, ${ }^{65}$ these metabolic changes are not always reflected in the organs. As has been pointed out by numerous clinical and experimental findings, the changes of MPS content of the serum are not always parallel with those of the tissues, e.g., periorbital and pretibial myxedema are not infrequent in patients suffering from thyroid hyperfunction. In hypothyrotic patients the entire skin and even the myocardium may be involved, whereas other organs may remain unaffected. Similar results have been reported by Krompecher and his collaborators ${ }^{64,66}$ who found a significant increase of serum hexosamine level in experimental hypothyrosis, but no such increase was noted in the hexosamine content of the liver.

Thyroidectomy does not appear to bring about increase of MPS content in the liver accoridng to our experiments; on the contrary, it appears to be decreased.

No essential changes were noted in thyroidectomized plus $\mathrm{CCl}_{4}$-treated rats. These findings seem to support the assumption that thyroidectomy gives a certain protection to the liver against the toxic effect of $\mathrm{CCl}_{4}$.

Considerable qualitative and quantitative changes were noted in the livers of non-thyroidectomized rats treated only with $\mathrm{CCl}_{4}$. The appearance of acid MPS and intensification of PAS positivity are signs of profound alteration. Increased PAS positive reaction is considered, in agreement with Graumann, as signs of depolymerization. ${ }^{67}$

The amount of total neutral MPS in the serum is $380 \mathrm{mg} \%$ and that of acid MPS is $80 \mathrm{mg} \%{ }^{17}$ These values are fairly constant under physiological conditions 
and such is the ratio of polymerized and depolymerized products. The constancy of tri- and disaccharide, as well as of galactosamine-glucosamine quotients within the MPS is, to some extent, indicative of normal metabolic conditions. This refers to those tissues (including the liver) in which neutral MPS are predominant and increase of acid MPS indicates a pathologic metabolism.

Of the numerous biological effects of acid MPS $24,68,69$ their essential part played in fat metabolism and atherogenic processes ${ }^{3,70-72}$ is now indisputable. We call attention to this function of acid MPS since liver cirrhosis is considered by some authors to be a sclerogenic disease. ${ }^{75}$ The presence of acid MPS may be one of the factors in the development of cirrhosis. It is certainly not accidental that increased amounts of MPS, similar to those found in the course of $\mathrm{CCl}_{4}$ treatment, were found in other pathologic processes of the liver; e.g., in amyloidosis. ${ }^{10}$ Thyroidectomy seems to counteract the toxic effect of $\mathrm{CCl}_{4}$ treatment, consequently the acid MPS is absent, the structure of the liver remains, on the whole, unaltered. Thus, thyroidectomy appears to be able to protect the liver against the damaging effect of $\mathrm{CCl}_{4}$ treatment.

In this connection another question was raised, namely, why does $\mathrm{CCl}_{4}$ treatment in itself bring about qualitative changes in the liver? There are various hypotheses in this respect. The activity of certain enzymes (hyaluronidase, heparinase) may diminish owing to the toxic effect of $\mathrm{CCl}_{4}$. We have to consider the hypothesis of Krompecher ${ }^{76}$ as well, according to which increased production of MPS occurs in hypoxic tissues. Krompecher believes that the same mechanism is working here as in cartilage formation where MPS (essential components of cartilage ground substance) are produced owing to deficient vascularization and tissue hypoxia due to pression.

As has been already mentioned, the livers of $\mathrm{CCl}_{4}$-treated rats displayed depolymerization. Increased amounts of depolymerization products may be found in processes of degeneration of fibrinoid, amyloid or selerotic types and even in regeneration. ${ }^{17,77,78}$ Their presence may be important in growth of malignant tumors and in the formation of metastases ${ }^{77}$ in infection, toxicosis and hyperergic states. ${ }^{77,79}$ Absence of depolymerization products may indicate absence of degeneration or regeneration processes, i.e., in such cases the toxic effect is counteracted as has been verified in the livers of thyroidectomized rats treated with $\mathrm{CCl}_{4}$.

In processes of degeneration large amounts of tryptophan are present as demonstrated by Schauenstein ${ }^{78}$ using UV spectrographic method. In previous experiments we have investigated the spontaneous and adaptive synthesis of tryptophan pyrrolase (TPO) enzyme. Thyroidectomy was found to increase adaptive enzyme synthesis, whereas decrease of both spontaneous and inductive enzyme syntheses occurred on $\mathrm{CCl}_{4}$ treatment. No decrease in activity was observed on $\mathrm{CCl}_{4}$ treatment following thyroidectomy; on the contrary, a certain decrease was noted. ${ }^{59}$ Diminution of TPO activity results in accumulation of tryptophan which is concomitant with accumulation of depolymerization product: 
in processes of degeneration, as has been confirmed by Schauenstein. ${ }^{78}$

Comparison of these two findings refers to a correlation between tryptophan and MPS metabolisms. Increase of TPO activity and decrease of depolymerization, as noted after thyroidectomy, as well as diminution of enzyme activity and increased depolymerization, as was observed in the liver injuries caused by $\mathrm{CCl}_{4}$, seem to be interrelated and may determine the favorable or damaging effect of metabolic processes on the liver.

Mention should be made of the histochemical findings concerning the livers of thyroidectomized rats. Such livers display only a quantitative change, namely, a moderate decrease of neutral MPS. Quantitative change in itself may affect the nutritional and biological conditions of a given organ. While protein-carbohydrate complexes accumulated in atherotic tissues have a damaging effect on the nutrition of the liver, decrease of MPS level due to hypothyrosis may improve it. In such cases more active metabolic processes may take place in which the possibility of increased capacity of the enzyme system for inactivating estrogen cannot be exlcuded.

The histological results were entirely concordant with the histochemical findings. $\mathrm{CCl}_{4}$ treatment was found to bring about severe impaiment of the liver tissue (disorganization of the plasma, vacuolization, cirrhotic connective tissue proliferation). The striking increase of mastocytes seems to be of particular interest, which may be connected with the appearance of acid MPS. ${ }^{48}$ Such manifestations were not encountered after previous thyroidectomy, which demonstrates the protective role of thyroidectomy.

\section{References}

1) Levene, O.A. Hexosamines and Mucoproteins. Monographs on Biochemistry, London \& New York, 1925.

2) Fonnesu, V. La determinazione delle mucoproteine (sieromucoide) del siero nell' ambito delle epatopatie. Minerva med., 1960, 51, 4234-4237.

3) Gerö, S., Farkas, K., Gergely, J., Jakab, L., Székely, J., Virág, S. \& Czuppon, A. A cholestrin-atherosclerosis gátlása beta-lipoproteinnel történö immunizálás utján. Orv. Hetil., 1960, 101, 1441-1447.

4) Orlorszkaja, C.Y. Beszámoló a pathologus-anatómus szakcsoport 1958. évi nagygyüléséröl (Héviz,1958, szepf. 26-28). Orv. Hetil., 1958, 99, 1760.

5) Tustanovszkij, A.1. Beszámoló a pathólogns-anatómus szakesoport 19.58. évi nagygyüléséröl (Héviz, 1958. szept. 26-28). Orv. Hetil., 1958, 99, 1760.

6) Tustanovszkij, A.A., Zaides, A-L., Orlovszkaja, G.V.\& Mikhailov, A.N. Tovye dannye o stroenii kollagena. Orv, Hetit., 1954, 97, 121-124.

7) Banga, I. The role of polysaccharides in connective tissue. Acta morph. Hung., 1959, Suppl. 8, 8-13.

8) Banga, I. A bör biokémiája - enłmitukus lebontása. Börgyógy. vener. Szle, 1960 , 36. $120-126$.

9) Balo, J., Szab6, I. \& Banga, I. On the effect of collagen mucoproteinase on the neutral mucopolysaccharides of collagen fibers. Acta histochem., 1960, 9, 69-75.

10) Bücskov in Bolsaja Medicinszkaja Enciklopedia. Moszkva, 1961, 19, 422.

11) Catchpole, H.R. Serum and tissue glycoproteins in mice bearing transplantable tumors. Proc. Soc. exp. Biol. Med., 1950, 75, 221-223.

12) Farkas, K. Beszámoló a patológus-anatómus szakesoport 1958. évi nagygyüléséröl 
(Heviz, 1958, szept. 26-28). Orw. Hotil., 1958, 99, 1760.

13) Gersh, I. Ground substance and plasticity of connective tissues. Harvey Lect. (19491950), 1952, 45, 211-241.

14) Greenspan, E.M. Survey of clinical significance of serum mucoprotein level. Arch. intern. Med., 1954, 93, 863-874.

15) Grépály, A., Metz. O. \& Both, G. Szérumglukoproteid-meghatározás gyermekkori tuberkulozisban. Orv. Szle, 1960, 6, 211-216.

16) Józsa, L. \& Lusztig. (x. Az aortafal mucopolysaccharida tartalmának vizsgálata kisérletes hyper-és hypothyreosisban. Kisérl. Orostud., 1965, 17, 590-595.

17) Módy, J. A vérplazma glukoproteidjei és mukopolyszacharidjai. Orv. Szle, 1961, 7, $72-77$.

18) Osváth, S., Bánhidi, E. \& März, I. A vér fibrinogen és hexosamin meghatározásának jelentösége tüdöbetegségeli differenciáldiagnosztikájában. Tuberkulózis, 1962, 15 , $345-350$.

19) Piukovich. I., Bábor, M. \& Széll, A. A serum-fehérjékben kötött szénhydrátok alakulása és a Middlebrook-Dubos reakcio nemiszervi gömökorral kapcsolatban. Tuberkulózis 1960. 13, 221-223.

20) Shinagawa, S., Maki. M. \& Yoshida, H. Serum protein-bound polysaccharides in patients with cancer of the cervix. J. Jap. obst. gynec. Soc., 1956, 3, 269-276.

21) Shinagawa, S., Maki, M. \& Yoshida, H. Increase in proteinbound polysaccharides level in patients with cervix cancer (especially in very earlier stages). Gann, 1956, 47, 256.

22) Sontagh, F., Glós, I. \& Mihály. S. Sugártherapia hatása portiocarcinomás beteg serumának polysaccharid-szintjére. Or. Hetil, 1960, 101, 1517-1520.

23) Fekete, S. A terhességi toxicosisok neuroendokrin vonatkozásai. Orv. Hetil., 1955, 96. 1009-1012.

24) Horn, Z. A heparin theripiás értékelése. Révai ny. Budapest, 1962.

25) Banga, I. Beszámolo a patológus-anatómus szakesoport 1958. évi nagygyüléséröl (Heviz, 1958. szept. 26-28). Orv. Hetil., 1958, 99, 1760.

26) Berencsi. G. \& Malatinszky, St. On the role of polysaccharides with reference to in vitro propagation of mycobacterium tuberculosis. Zdl. Bakt. (Orig.), 1961, 183, 513-516.

27) Berencsi, Gy. \& Krompecher, T. Mukopolysacchariclák a tuberkulózis szöveti pathomechanizmisában. Tuberkulózis, 1960, 13, 97-101.

28) Malatinszky. I. \& Berencsi, Gy. A felület szerepe a mylkobaktérium tbe szaporodásában. Hajdı-Bihar megyei Kórház Tudományos Emlékkönyve Debrecen (Hung.), 1961, pp. $209-221$.

29) Berenesi, G.. Krompecher, St. \& März, I. Experimental data on the correlation between hepatic and thyroid functions. Acta anat., 1964, 60, 507-515.

30) Ducommun. P. L'action de l'ACTH, de la cortisone et de la désoxycorticostérone dans l'inflammation. Schweiz. ned. Wschr., 1952, 82, 808-813.

31) Heilmeyer, L. Algemeine klinische Bedeutung des Hypophysen-Nebennierenrindensystems. Klin. Wschr., 1952, 30, 865-873.

32) Józsa, L., Perneczy, M., Szederkényi, Gy. \& Lusztig, G. Kémiai thyreoidektómia, thyreoidea kezelés es thyreotrop hormon hatása nyulban a vér mucopolysaccharida tartalmára. Kisérl. Orvostud., 1964, 16, 642-647.

33) Ludwig, A.W., Boas. N.F. \& Soffer, L.J. Role of mucopolysaccharides in pathogenesis of experimental exophthalmos. Proc. Soc. exp. Biol. Med., 1950, 73, 137-140.

34) Selye, J. The Physiology and Pathology of Exposure to Stress. Acta Inc. Mod. Publ. Montreal, 1950.

35) Straub, F.B. Biokémai. Medicina, Buclapest, 1961,

36) Taubenhaus, M. \& Amromin, C.D. The effects of the hypophysis, thyroid, sex steroids, and the adrenal cortex upon granulation tissne. J. Lab. chin. Med., 1950, $36,7-18$.

37) Brux, J. \& Boistesselin. R. Modifications histologiques et histochimiques du tissue conjonctif sous l'influence de différentes actions hormonales. Presse méd., 1953, 83. $600-604$. 
38) Csik, L. \& Podhragyai, L. Az izületi szövetek terhesség alatti változásainak vizsgálata. Orn. Hetil., 1956, 97, 961-964.

39) Duran-Reyhals, F. Tissue permeability and spreading factors in infection; Contribution to host: parasite problem. Bact. Rev., 1942, 6, 197-252.

40) Gibian. H. Mucopolysaccharide und Mucopolysacckaridasen. Deuticke, Wien, 1959.

41) Ludwig, A.W. \& Boas, N.F. Cit. in L. Matkó, A kötöszövet alapállományának pathologiaja. Orv. Hetil., 1954, 95, 72-78.

42) Lurie, M.B. \& Zapposodi, P. Effect of chronie gonadotropin on spread of particulate substances in skin of rabbits. Arch. Path., 1942, 34, 151-166.

43) Ogston, A.G., Philpot, J. St. L. \& Zuckermann, S. Observations related to swelling of sexual skin in rhesus monkeys. J. Endocr., 1939, 1, 231-238.

44) Greenspan, E.M. \& Dreiling, D.A. Serum mucoprotein level in differentiation of hepatogenic from obstructive jaundice. Arch. intern. Med., 1953, 91, 474-486.

45) Schaffner, F., Scherbel, A.L. \& Lytle, R. Electrophoretic serum glycoproteins in acute viral hepatitis. J. Lab. clin. Med., 1956, 48, 551-558.

46) Werner, I. On regeneration of serum polysaccharide and serum proteins in normal and intoxicated rabbits. Acta physiol. scand., 1949, 19,27-42.

47) Amprino, R. Autoradiographic research on 835 -sulphate metabolism in cartilage and bone differentiation and growth. Acta anat., 1855, 24, 121-163.

48) Asboe-Hansen, G. On the structure and functions of the mast cell. Connective Tissue Symposium vol. 1. Blackwell Scient. Publ., Oxofrd, 1957.

49) Gersh, I. \& Catchpole, H.R. Organizatioa of ground substance and basement membrane and its significance in tissue injury, disease and growth. Amer. J. Anat., $1949,85,457-521$.

50) Berencsi, G., Krompecher, St. \& März, I. Contribution to the correlation between hepatic function and mucopolysaccharide household. Acta anat., 1964, 57, 232-242.

51) Gergely, J. \& Kulcsár, A. A hormonális milieu és a májmüiködés összefüggései. Acta pharm. Hung., 1963, 33, 275-276.

52) Kulcsár, A. \& Kulcsár-Gergely, J. Versuche mit Oestrogenbelatungen bei hypothyreotischer Tiere. Naturwissenschaften, 1962, 49, 610.

53) Kulesár, A. \& Kulcsár-Gergely, J. Über der Leberschutzwirkung der Hypothyreose. Natumvissenschaften, 1963, 50, 693-694.

54) Kulesár, A. \& Kulcsár-Gergely, J. Die Östrogenemfindlichkeit der Hypothyreotischen und leberkranken Tiere. Naturwissenschaften, 1963, 50, 306.

55) Kulesár-Gergely, J., Kulcsár, A. \& Dévéyyi, I. The protective effect of thyroidectomy and ovariectomy on experimental liver lesion. Tokoku J. exp. Med., 1964, 84, 256-258.

56) Kulcsár, A. \& Kulcsár-Gergely, J. The influence of hormonal disturbances on the survival of liver damaged animals. Tohok J. exp. Med., 1966, 89, 315-320.

57) Kulcsár, A. \& Gergely, J. The role of endocrine regulation in the protection of the liver. Conventus tertins Medicinae Internae. Akadémiai Kiadó (H.ung.), Budapest, 1965.

58) Kulcsár-Gergely, J. \& Kulcsár, A. Leberfunction während der Hypothyreose. Naturuissenschaften, 1962, 49, 610.

59) Kulcsár, A., Gergely, J., Síri, B., Kirilina, Sz. \& Dán, S. A máj enzymadaptatios képességénel hormonális szabályozása. Elöadäs. 2. Endokrinológiai Vándorgyülés, Debrecen (Hung.), 1965. szept. 2-4.

60) Kaufmann, G. Tetrachlorkholenstoff-Zirrhose und Restauration der Leber. Beitr. path. Anat., 1953, 113, 253-270.

61) Ritter, H.B. \& Oleson, J.J. Combined histochemical staining of acid polysaccharides and 1,2 glycol groupings in parafin sections of rat tissues. Amer. J. Path., 1950, 26, $639-645$.

62) Hale, C.W. Histochemical demonstration of acid polysaccharides in animal tissues. Nature, $1946,157,802$.

63) Hotchkiss, R.D. A microchemical reaction resulting in the staining of polysaccharide structures in fixed tissue preparations. Arch. Biochem., 1948, 16, 131-141. 
64) Krompecher, St., Oláh, E.H., Hadházy, Cs., Fornet, B., Balogh, G., Berencsi, G.. Szilágyi, J., Mészáros, L. \& Ĺ́szló, M.B. Changes of the blood mucopolysaceharide level in hypo- and hyperthyreosis, and diseases attended by tissue destruction. Actn norph. Hung., 1959, Suppl. 9, 17.

(55) Krompecher, St., Fornet, B., Balogh, G., Oláh, E.H. \& Liszó, M.B. Mucopolysaccharides and thyroid function. Nature, 1961, 189, 670.

66) Ĺszló, M.B. \& Krompecher, St. Schilddrüsentätigkeit nnd Mucopolysacharide; ihr Zusammenhang in morphologischer, histochemischer und biochemischer Darstellung. Z. Anat. Entwickl.-Gesch., 1962, 123, 87--96.

67) Graumann, W. Die histochemische Reaktion der Knorpelgrundsubstanz mit Perjodsäure und Bleitetracetat. Mikroskopie, 1953, 8, $218-225$.

68) Jancsó, M. Cit. in E. Perlick: Anticoagulantien. Thieme, Leipzig, 1939.

69) Pillemer, L., Landy, M. \& Shear, M.J. The properdin system and immunity. J. exp. Med., 1957, 106, 99-110.

70) Gergely, J. A\% érelmeszesedésröl. Medicina, Budapest, 1962.

71) Gerö, S. Az atheroselerosis kutatisok mai állísa. Orv. Hetil., 1959, 100, 889-897.

72) Gerö, S., Gergely, J., Jakab. L., Székely, J., Virig, S., Farkas, K. \& Czuppon, A. Inhibition of cholesterol atherosclerosis by immunisation with beta-lipoprotein. Lancet. 1959, 2, 6-7.

73) Magyar, I. Fischer, A. A máj és az epeutak. Akadémiai Kiado (Hung.), Budapest, 1956 .

74) McCallum, C.M. Textbook of Pathology. 6th ed., Sannders, Philadelphia, 1938.

75) Mallory, F.B. Pathological Technique. Saunders, Philadelphia, 1938.

76) Krompecher, St. Hypoxybiose und Mucopolysaccharid-Bildung in der Differenzierung und Pathologie der Gewebe sowie über den Zusammenhang zwischen Schilddrüsenfunktion und Mucopolysaccharide. Nova Acta Leopolodina, 1960, 22, No. 146.

77) Matkó, L. A kötöszövet alapállományának pathologiája. Orv. Hetil., 1954, 95, $72-78$.

78) Schauenstein. E. \& Rumpf, G. Physikochemische Befunde an bindegewebigen Hya. lin. Z. Biol., 1952, 105, 117-133.

79) Seichert.Winzle, R. Cit. in L. Matko, Orw. Hetil., 1954, 95, 72.

[ Illustrations follow] 


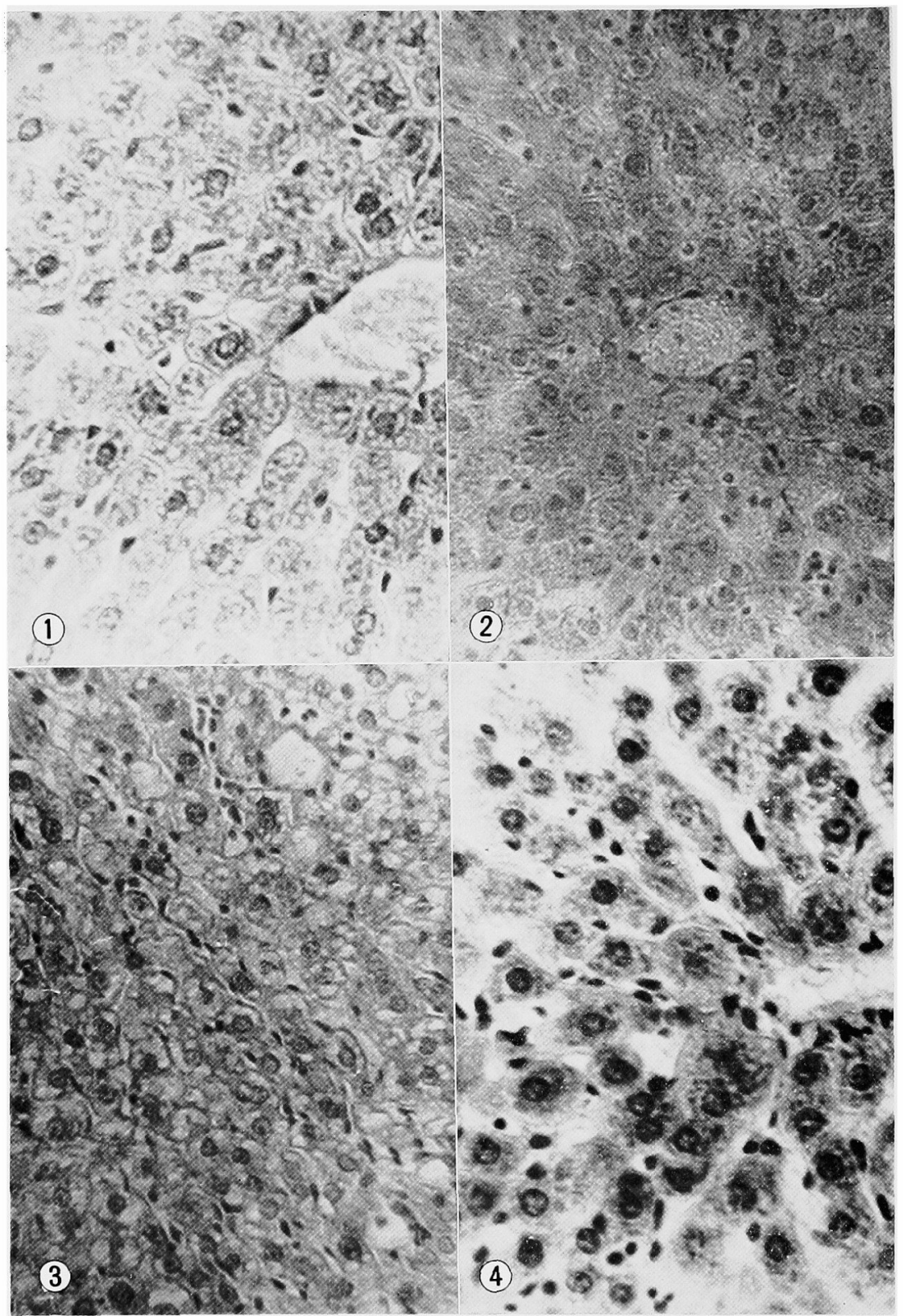

Fig. 1. Liver of control rat. Staining: hematoxylin-chromotrop. $\times 400$.

Fig. 2. Liver of thyroidectomized rat. Staining: hematoxylin-chromotrop. $\times 400$.

Fig. 3. Liver of carbontetrachloride treated rat. Staining: hematoxylin-chromotrop. $\times 400$.

Fig. 4. Liver of thyroidectomized plus $\mathrm{CCl}_{4}$-treated rat. $\times \mathbf{4 0 0}$. 


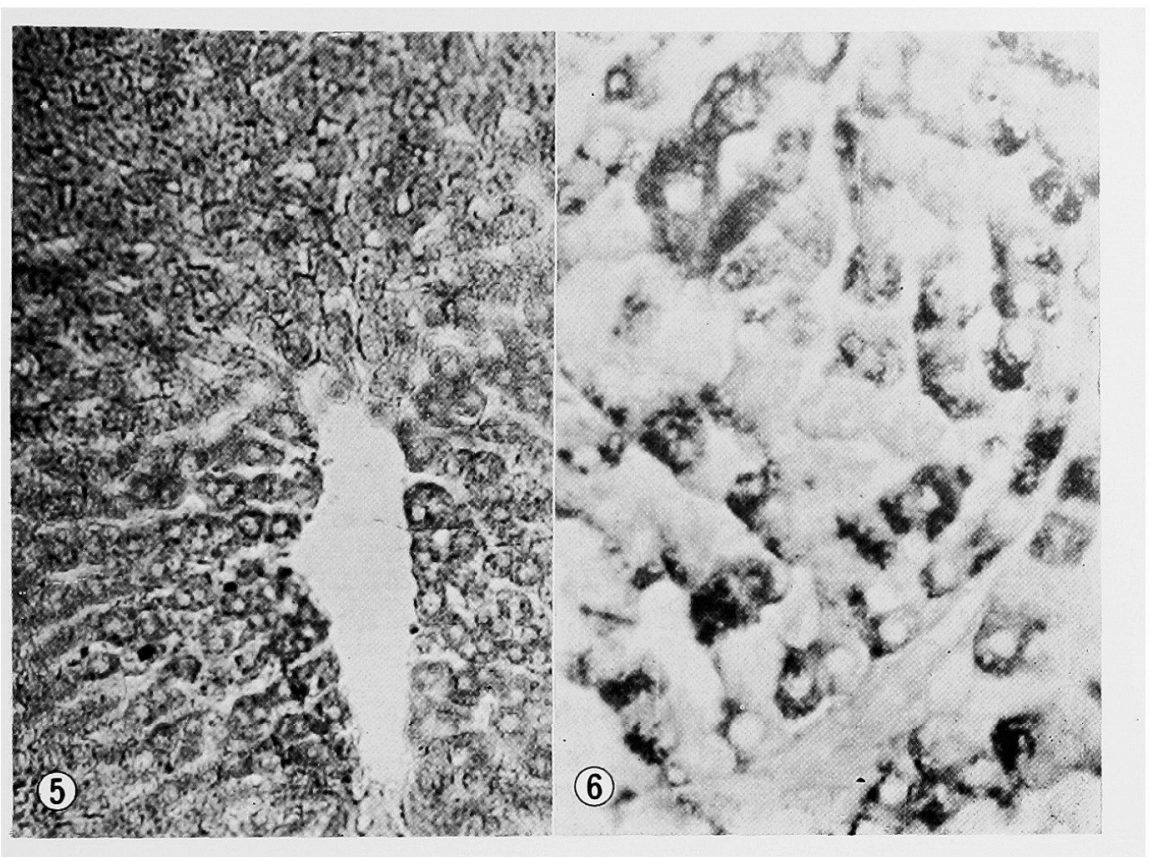

Fig. 5. Liver of control rat. Ritter-Oleson's technique. $\times \mathbf{4 0 0}$.

Fig. 6. Liver of thyroidectomized rat. Ritter-Oleson's technique. $\times \mathbf{4 0 0}$.

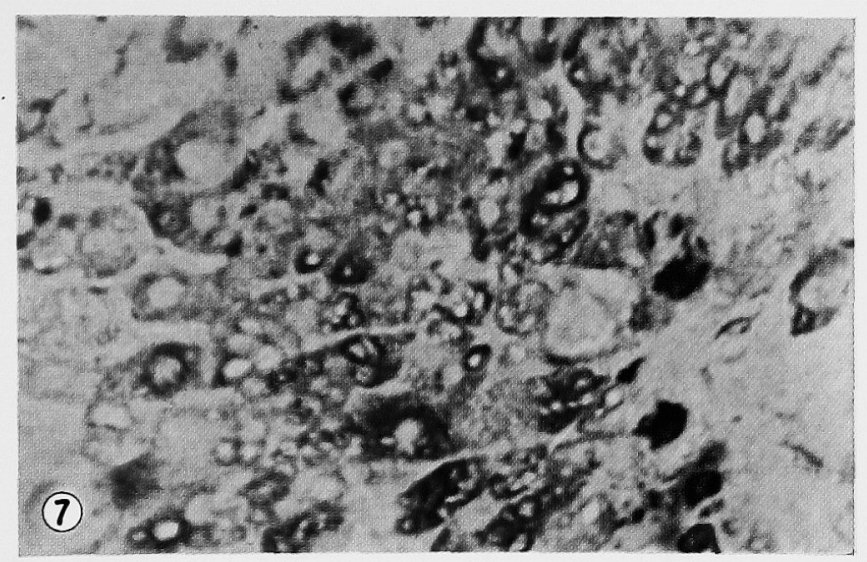

Fig. 7. Liver of $\mathrm{CCl}_{4}$ treated rat. Ritter-Oleson's technique. $\times \mathbf{4 0 0}$. 


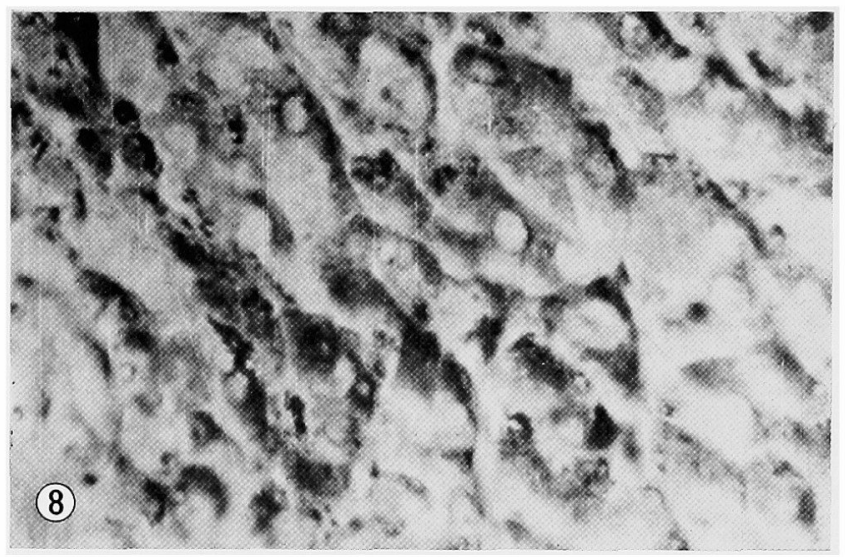

Fig. 8. Liver of thyroidectomized plus $\mathrm{CCl}_{4}$-treated rat. Ritter-Oleson's technique. $\times 400$. 